Y-12

OAK RIDGE

$\mathrm{Y}-12$

PLANT

LOCKHEED MATTIN
RECEMII:

FEB $1 \& 1097$

OSTI

\title{
Surplus \\ Highly Enriched Uranium \\ Disposition Program Plan
}

Lockheed Martin Energy Systems, Inc. Oak Ridge Y-12 Plant

October 1996

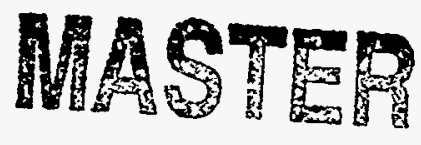

MANAGED BY

LOCKHEED MARTIN ENERGY SYSTEMS, INC. FOR THE UNITED STATES

DEPARTMENT OF ENERGY

Prepared by the Oak Ridge Y-12 Plant Oak Ridge, Tennessee 37831, managed by Lockheed Martin Energy Systems, Inc., for the U.S. DEPARTMENT OF ENERGY under contract DE-AC05-84OR21400 


\section{DISCLAIMER}

This report was prepared as an account of work sponsored by an agency of the United States Government. Neither the United States Government nor any agency thereof, nor any of their employees, makes any warranty, express or implied, or assumes any legal liability or responsibility for the accuracy, completeness, or usefulness of any information, apparatus, product, or process disclosed, or represents that its use would not infringe privately owned rights. Reference herein to any specific commercial product, process, or service by trade name, trademark, manufacturer, or otherwise, does not necessarily constitute or imply its endorsement, recommendation, or favoring by the United States Government or any agency thereof. The views and opinions of authors expressed herein do not necessarily state or reflect those of the United States Government or any agency thereof. 


\section{Lockheed Martin Energy Systems, Inc. Oak Ridge Y-12 Plant}

\section{Surplus Highly Enriched Uranium Disposition Program Plan}

October 1996

LOCKHEED MATINA 
This page intentionally left blank. 


\section{DISCLAIMER}

Portions of this document may be illegible in electronic image products. Images are produced from the best available original document. 


\section{TABLE OF CONTENTS}

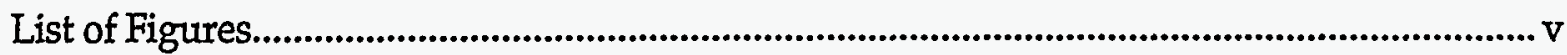

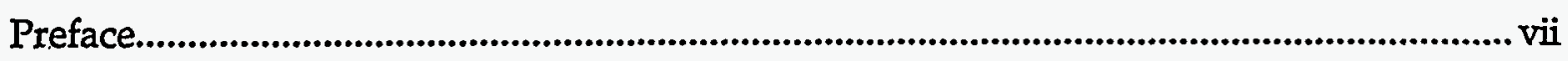

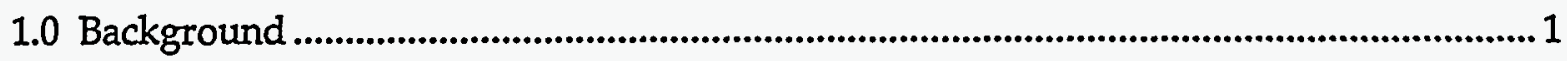

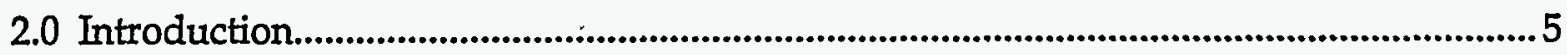

3.0 HEU Disposition Mission............................................................................................. 9

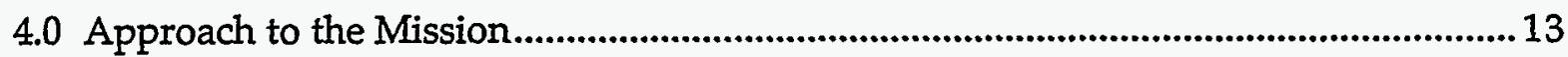

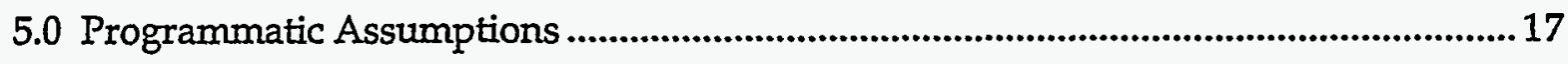

6.0 Roles and Responsibilities ........................................................................................ 19

7.0 Summary Level Schedule .................................................................................................. 25

8.0 Budget and Resource Estimates...............................................................................27

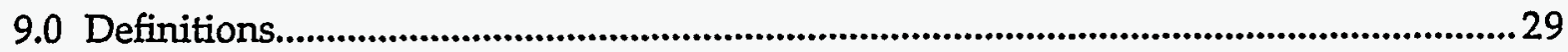

10.0 Abbreviations, Acronyms, and Initialisms ...........................................................31

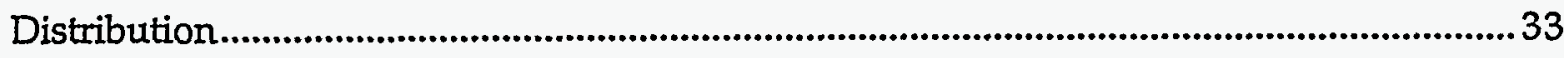


This page intentionally left blank. 


\section{LIST OF FIGURES}

Figure

Title

Page

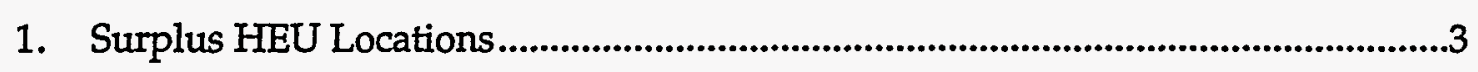

2. Surplus Weapons HEU Life Cycle ........................................................................6

3. HEU Disposition Program Functional Hierarchy.............................................10

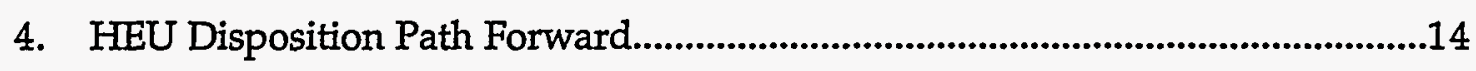

5. Disposition Program Information Flow ..............................................................20 
This page intentionally left blank. 


\section{PREFACE}

The purpose of this document, Surplus Highly Enriched Uranium Disposition Program Plan, Y/ES-162, is to provide upper level guidance for the program that will down blend (for use as commercial nuclear reactor fuel or low-level radioactive waste) the Department of Energy (DOE) highly enriched uranium (HEU) which is surplus to national security needs. As the organization with primary responsibility for providing support to the DOE Office of Fissile Material Disposition (OFMD) in developing and implementing plans for dispositioning surplus HEU, the Oak Ridge Y-12 Plant Highly Enriched Uranium Disposition Program Office (HDPO) is issuing this program plan. This plan provides background information, establishes the scope of the disposition activities, provides an approach to the mission and objectives to be achieved, identifies programmatic assumptions that address known issues, defines major roles and responsibilities, provides for summary level schedules and milestones, and addresses budget and resource requirements. This document is not intended to be a detailed plan of action which addresses all programmatic activities related to the disposition of surplus HEU, since many of the requirements, issues, and activities are still unknown. It is intended to outline the overall mission and objectives of the program. As the ramifications of the disposition program become better defined, this document will be updated so that it reflects the latest programmatic information.

While this plan is a HDPO document and primarily applicable to that office, it cannot be implemented without the concurrence and support of OFMD, Defense Programs, and other appropriate DOE Headquarters' (HQ) representatives such as the Office of Nuclear Energy and the Office of Nonproliferation and National Security. Other DOE sites which currently retain surplus HEU also play a major role in achieving the DOE mission of dispositioning surplus HEU in a permanent and cost effective manner. This document should provide a general basis for integration of HEU disposition efforts among all applicable sites.

The HDPO recognizes the need to make this plan consistent with similar documents that may be created by OFMD and other DOE organizations. 
This page intentionally left blank. 


\subsection{BACKGROUND}

The end of the Cold War created a legacy of weapons-capable fissile material. Global stockpiles of this material threaten national and international security through potential proliferation of nuclear weapons and could result in environmental safety and health consequences if the material is not properly stored, handled, and managed.

Demonstrating a commitment to nonproliferation, the President of the United States (U.S.) announced on March 1, 1995, that approximately 200 metric tons ( $t$ ) of U.S. fissile material is excess to national security needs. At the time of issuance of this document, a total of approximately $174 \mathrm{t}$ of HEU had been declared excess to national security needs.

The President's announcement concerning excess fissile materials signaled a change in national priorities and resulted in significant changes in the missions of many DOE sites. DOE sites with historical missions of weapons production began the transition to downsized stockpile maintenance sites and/or environmental cleanup sites. In addition to the excess weapons material taken from the stockpile, weapons site cleanup activities are expected to yield additional quantities of excess materials. Much of this excess material has potential commercial value as nuclear reactor fuel. DOE recognized the need for increased coordination among affected sites and an integrated disposition process in order to reduce overall operation and management costs and to provide a return to the U.S. Treasury.

Historically, DOE has dispositioned HEU that was no longer needed for weapons use through transfer to other programmatic uses, such as fuel for research reactors. A small fraction (about 10 percent) of the $174 t$ recently declared excess has been reserved for such uses. This program plan does not address those programmatic transfers but deals only with the remainder, which is "surplus" with respect to DOE program needs. This "surplus HEU" will be dispositioned by down blending for commercial nuclear reactor fuel or low level radioactive waste (LLW). Within this program plan, reference is made to the entire 174t as surplus, because the specific inventories reserved for programmatic needs have not been explicitly identified. Planning discussed herein must encompass all of the excess material until it is explicitly known which inventories will be used programmatically and which will be dispositioned as surplus.

The OFMD has prepared a Surplus HEU Disposition Environmental Impact Statement (EIS) that describes expected environmental impacts of down blending surplus HEU to destroy its weapons capability. The EIS describes various alternatives for blending surplus HEU with low-assay uranium to achieve a low enriched uranium (LEU) product of $<20 \%$ assay. This assay is considered to be the threshold for weapons 
capable material. The HEU inventories covered by the EIS are those declared excess in the President's March 1, 1995 announcement and are the focus of this program plan.

The Oak Ridge, Tennessee $Y-12$ Plant has long been designated as the DOE lead site for managing uranium inventories. It has now been established as lead laboratory for surplus HEU disposition and has been charged with providing options for safe, secure, and environmentally sound management and disposition of surplus HEU. This surplus HEU is currently stored at many sites across the DOE weapons complex (see Figure 1). The location, general form, and amount of surplus material at the various DOE sites is thoroughly documented. However, more detailed characterization of the surplus HEU, as to uranium isotopic content and of trace chemical impurities, is a significant early step in the disposition process. Another major step is the consideration of blending options to achieve a LEU product usable for commercial nuclear reactor fuel. This program plan outlines a path forward to accomplish these and other disposition tasks necessary to meet the end objective of surplus HEU disposition. 


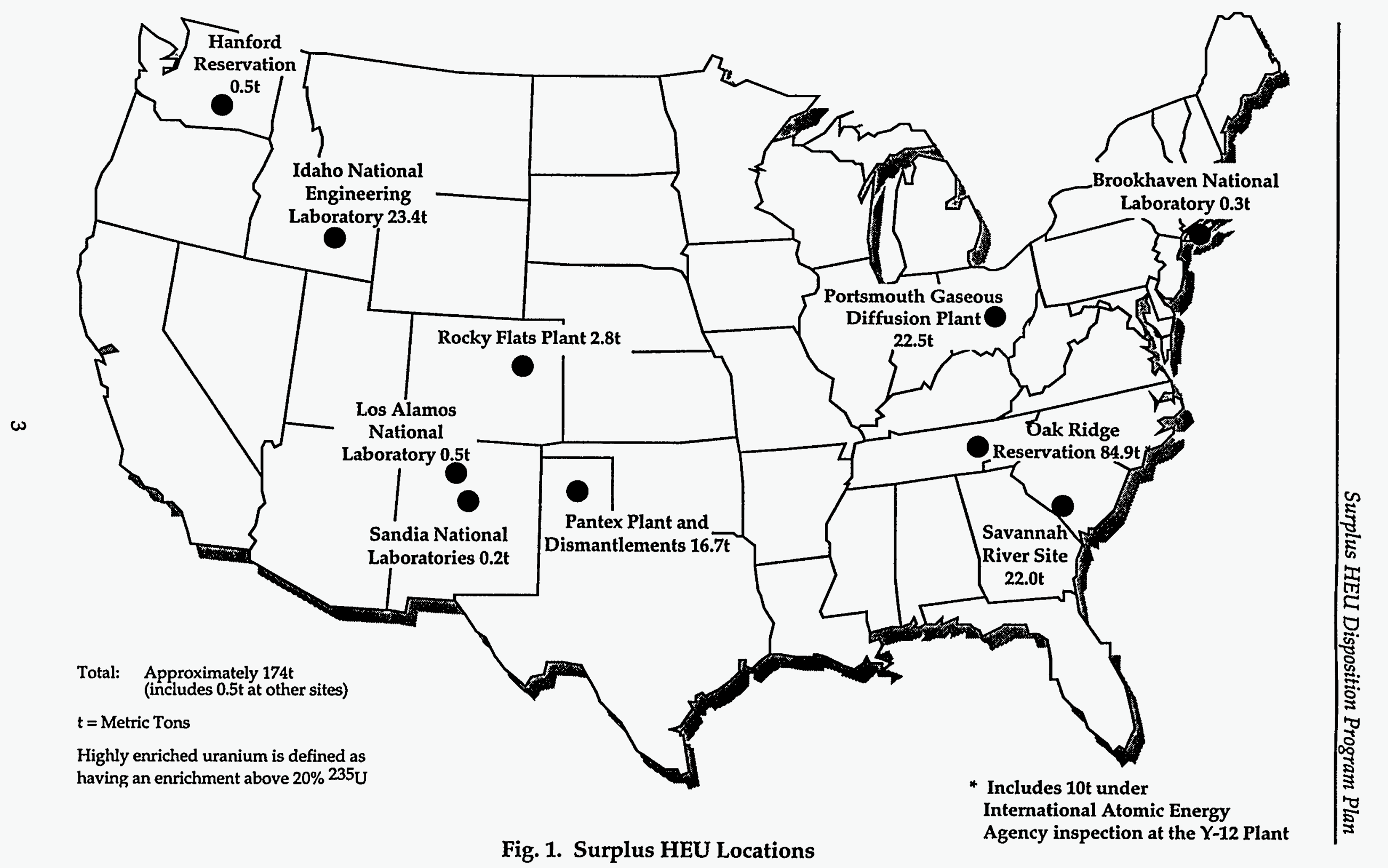


This page intentionally left blank. 


\subsection{INTRODUCTION}

The role of HDPO is to provide primary support to DOE OFMD in establishing and implementing plans for the disposition of surplus HEU inventories. This document represents the HDPO's plan for fulfilling that role.

There are a number of critical activities required to develop and implement a strategy for HEU disposition. Two of these activities are: (1) detailed characterization of the excess HEU inventory; and (2) establishing a baseline and change control process. The characterization effort is discussed in Section 4.0 of this report. Once surplus materials are identified and characterized, a baseline of available surplus material must be established and a change control process implemented. Since multiple DOE and non-DOE organizations may have an interest in the surplus inventories, the HDPO should be notified of all activities which change the amount, location, characteristics; or availability of HEU.

Disposition of surplus HEU will involve blending HEU into LEU for either commercial nuclear reactor fuel or LIW. Figure 2, Surplus Weapons HEU Life Cycle, provides a pictorial process flow of the surplus HEU from initial mining through ultimate disposition. Initially, HEU inventories must be identified and prioritized for down blending, including both weapons and non-weapons materials. Most of the surplus materials can be down blended efficiently. Some will be difficult to down blend for reactor fuel because of impurities or isotopic composition. However, the entire surplus inventory will be down blended for nonproliferation. Priority may be given to certain surplus materials to alleviate any safety, environmental, and security concerns. This program plan will discusses the issues and decision points involved in selecting optimum paths forward for the various surplus HEU inventories.

The HEU Disposition Program is obligated to support the preferred alternative announced in the EIS and selected as the path forward in the Record of Decision (ROD) dated July 29, 1996. This decision is to maximize the HEU down blended for use as commercial nuclear reactor fuel and to down blend the remainder to LLW. Technologies considered include blending as uranium metal, uranium hexaflouride $\left(\mathrm{UF}_{6}\right)$, and uranyl nitrate solution.

The down-blended product provided as feed material to nuclear fuel fabricators could be provided in several forms including $U_{6}, U N H$ crystals, and uranium oxides. HEU that cannot be made into acceptable reactor fuel will be down blended to LLW at 0.9 percent assay for disposal. 


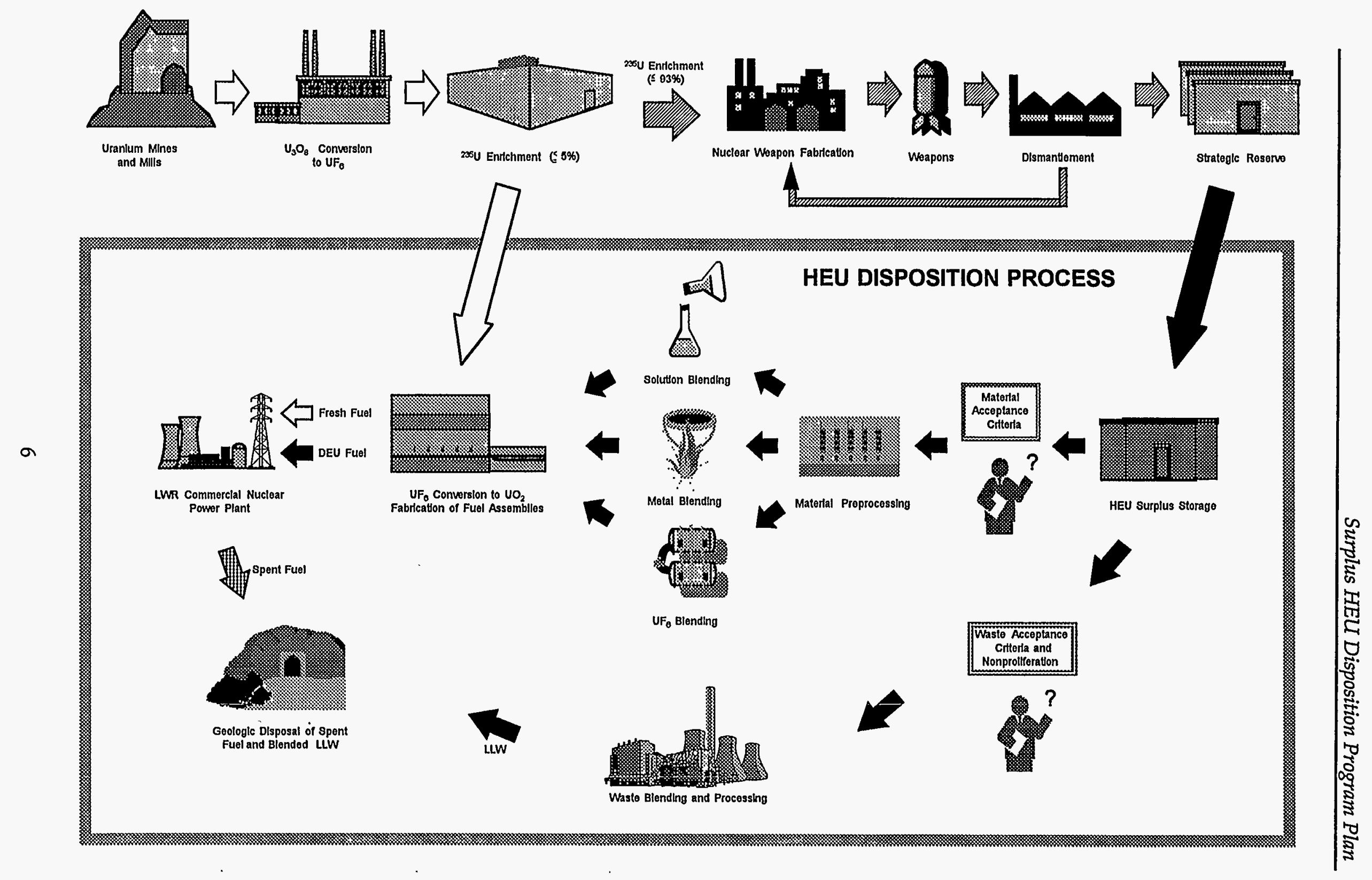

Fig. 2 Surplus Weapons HEU Life Cycle 
Four potential down-blending sites were identified by DOE in the EIS. Two are DOE installations: the Y-12 Plant in Oak Ridge, Tennessee; and the Savannah River Site (SRS) in Aiken, South Carolina. The other two are commercial facilities: Nuclear Fuel Services (NFS) in Erwin, Tennessee; and Babcock and Wilcox (B\&W) in Lynchburg, Virginia.

An essential part of the disposition decision is the establishment of criteria by the reactor industry for acceptance of derived enriched uranium (DEU) (see definition of DEU in Section 9.0). Cooperation with the fabricators of the fuel elements, the eventual users of the DEU, and other involved organizations such as Electric Power Research Institute (EPRI) and American Society for Testing and Materials (ASTM) will be required.

This program plan first identifies the mission of the OFMD and the objectives necessary to accomplish its mission. The approach and major HDPO tasks to achieve the mission are identified. Programmatic issues are described. Roles and responsibilities of organizations are detailed with respect to the objectives and mission of the OFMD. Summary level schedule and budget information for the overall program are also provided.

The HDPO will issue a separate implementation plan each fiscal year to supplement this program plan. Each annual implementation plan will describe specific tasks, budgets, and schedules for that fiscal year. 
This page intentionally left blank. 


\subsection{HEU DISPOSITION MISSION}

The mission of the DOE OFMD to reduce U.S. nuclear weapons capable stockpiles of surplus HEU directly supports the Record of Decision for the Disposition of Surplus Highly Enriched Uranium, issued on July 29, 1996. In the ROD, the DOE has decided to implement a program to convert the surplus HEU into a non-weapons-capable product by blending it down to low enriched uranium (LEU). This decision was derived from the overall DOE mission to support the U.S. nuclear weapons nonproliferation policy by reducing global stockpiles of excess weapons-usable fissile materials, and to recover the economic value of the materials to the extent feasible.

As illustrated in the HEU Disposition Program Functional Hierarchy, Figure 3, the primary mission of DOE is to reduce excess HEU. This mission is supported by the principal objectives of the program which are as follows:

1. Transfer ownership of $13 t$ of surplus HEU in the form of $\mathrm{UF}_{6}$ to the United States Enrichment Corporation (USEC) to be down blended to nuclear fuel at Portsmouth pursuant to the "Energy Policy Act of 1992". This objective was completed in 1994.

2. Transfer ownership of an additional $50 t$ of surplus HEU to the USEC to be down blended to LEU for commercial nuclear reactor fuel. This objective is currently in process.

3. Disposition the remaining $111 t$ of surplus HEU, as appropriate. Disposition includes transfer to DOE non-weapons programs, conversion to LEU for commercial nuclear reactor fuel (may include off-spec fuel), or conversion to LEU for disposal as LLW.

Included in this quantity is $10 t$ of surplus HEU placed under IAEA safeguards in 1994. This material, in the form of metal castings, is stored at the Y-12 Plant in a manner that makes it available to the IAEA for inspection. This material is awaiting further disposition.

This disposition objective will gradually evolve into several different projects, each of which covers a specific portion of the overall 111t of HEU. 


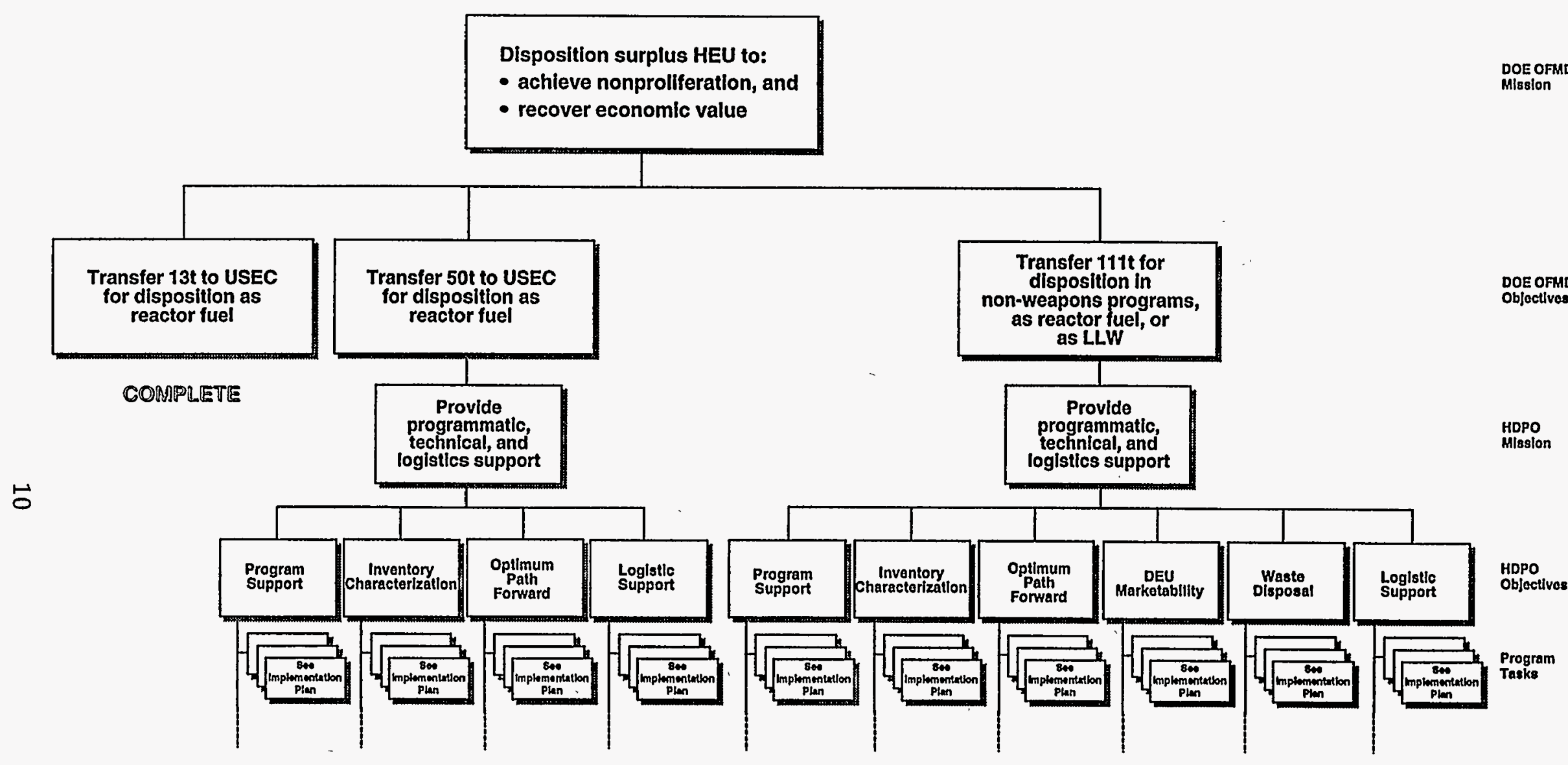

Fig. 3. HEU Disposition Program Functional Hierarchy 
The HDPO's mission is to support the OFMD disposition objectives, so that the OFMD mission can be successfully achieved in a timely manner. Specifically, the HDPO mission is to :

1. Provide DOE with programmatic, technical, and logistical support, as necessary, for the task of transferring 50t of surplus HEU to USEC's blending site.

2. Provide DOE with necessary programmatic, technical, and logistical support for the task of transferring $111 \mathrm{t}$ of surplus HEU to appropriate facilities for down blending to DEU for use as commercial nuclear reactor fuel or for disposal as LLW, or for transfer to appropriate DOE nonweapons programs (such as research reactors) for further use and disposition.

The transfer of $13 t$ of HEU in $\mathrm{UF}_{6}$ form to USEC at Portsmouth is complete and involves no HDPO support.

To satisfy the HDPO mission and objectives, essential tasks will be defined and implemented (see Figure 3). As stated in Section 4.0, Approach to the Mission, tasks are based on current needs of the program, and may change from year to year. Task details will be included in the annual implementation plans which supplement the program plan. 
This page intentionally left blank. 


\subsection{APPROACH TO THE MISSION}

To fulfill its mission of high quality and timely support to OFMD, HDPO has established objectives as shown in Figure 3. Specific HDPO task assignments to satisfy these objectives focus on the individual disposition objectives of the DOE. As the program progresses, emphasis within the DOE objectives may shift, and thus HDPO objectives are intended to be flexible and change accordingly. Some shift in emphasis and evolution of HDPO tasks has already occurred. Details of current task assignments will appear in an implementation plan, to be updated annually. All disposition activities will occur within the boundaries of legal and regulatory requirements. This includes full commitment to the application of related safety, environmental and safeguards in disposition of surplus HEU.

The total HEU discussed in this plan is $174 \mathrm{t}$. Of that, 13t has already been dispositioned by transfer to USEC. Of the remaining $161 \mathrm{t}$, DOE plans to transfer ownership of $50 t$ to USEC for down blending to LEU for commercial nuclear reactor fuel, with actual deliveries scheduled over a six-year period. The HDPO will develop a comprehensive path forward for this material and a more complete characterization of candidate inventories for this transfer. Specific inventory lots will be identified and appropriately designated for transfer. Logistical support will be provided to assure that the delivery schedule is met at minimum cost to DOE.

Much of the focus of HDPO tasks, however, is directed toward the longer term DOE objectives for the 111t of surplus HEU remaining after the 50t transfer to USEC. Part of the 111t will be identified for research reactor or other program use. While that material will not be included in the down blending for commercial nuclear reactor fuel or LLW, it will be made nonweapons-capable and dispositioned as spent nuclear fuel or waste. The remainder of the 111t will be the surplus that is destined for disposition under this program. The disposition path forward for this material is depicted on Figure 4.

Some of the HEU included in the $111 \mathrm{t}$ inventory will also require more comprehensive characterization to determine its attractiveness as commercial nuclear reactor fuel, and to make a final determination of whether specific inventories can be down blended for commercial nuclear reactor fuel or will be dispositioned as LLW. The inventory characterization process is complex because some attributes of the material that are important to the fuel industry were of little interest in weapons production, and consequently, detailed data are not available. Investigation into historical records may yield some of the required characterization; however, additional sampling and analysis will be required. 


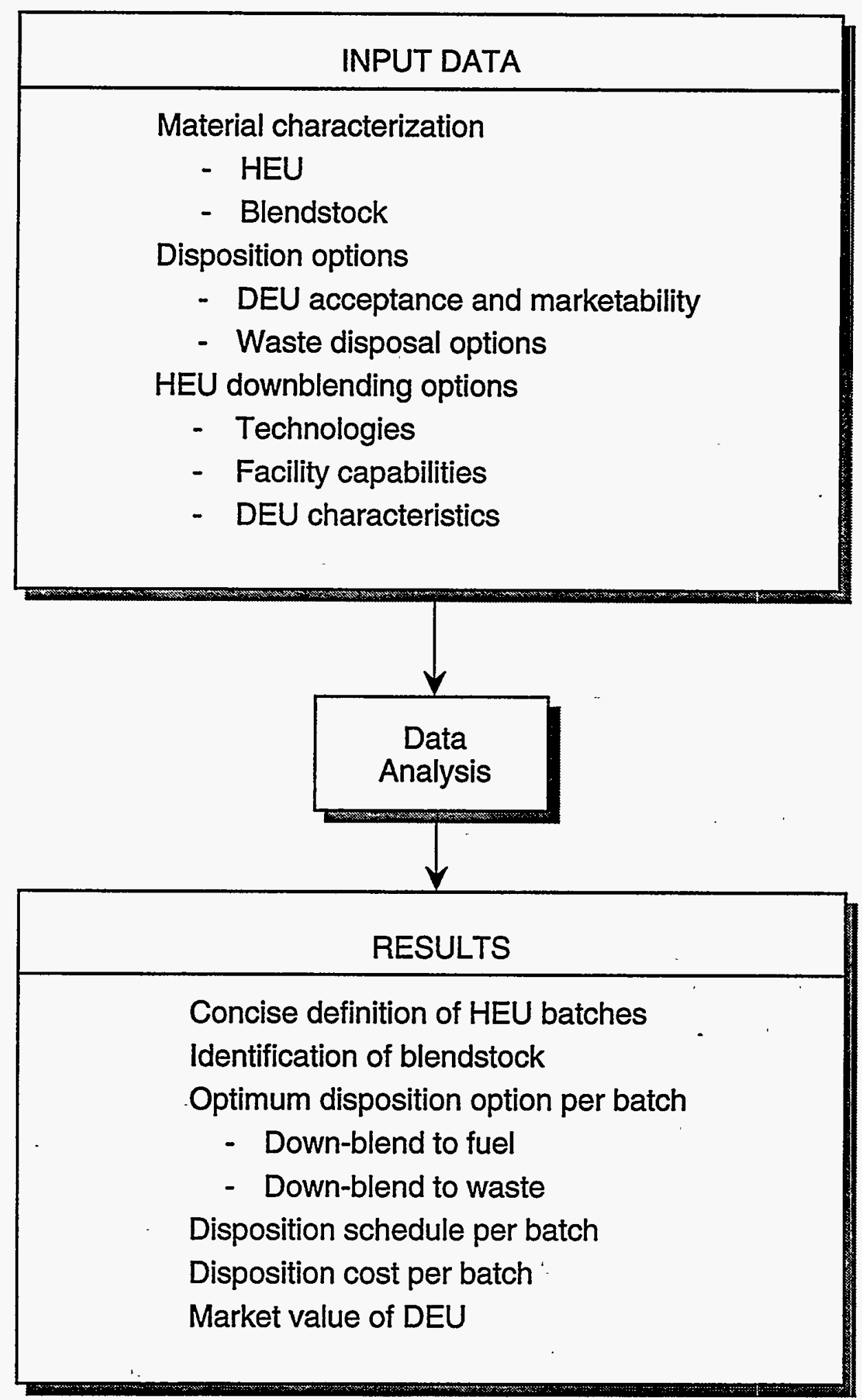

Fig. 4. HEU Disposition Path Forward 
A thorough investigation of down-blending technologies and facilities will be necessary in the development of an optimum path for disposition actions. A limited number of facilities have capability to process HEU, but none are ideally suited for down blending for commercial nuclear reactor fuel. The extent to which these facilities may be used for down blending, and the manner in which they are currently being used, has not been determined.

Interaction with the nuclear fuel cycle industry and an understanding of the uranium fuel cycle market will be required to resolve marketability issues related to chemical form and isotopic and chemical purity for blended fuel. How these issues are resolved may impact the optimum processing path and will be a factor in determining if the economic value of the HEU can be recovered.

The down blending of $\mathrm{HEU}$ will require large quantities of diluent uranium for blendstock. For the $\mathrm{UF}_{6}$ and metal blending technologies, the blendstock must be of the same form as the surplus HEU. Ongoing efforts to divest DOE of excess natural uranium (NU) and LEU may impact down-blending options and increase program costs. The HDPO will support divestitures which it believes are in the best overall interest of the DOE and taxpayers.

Down blending for waste disposal will likely not occur until late in the overall disposition program. However, options must be identified and evaluated long before the actual down blending and disposal are scheduled to take place. The EIS calls for this material to be down blended to an assay of 0.9 percent and disposed of as LLW. However, much work will need to be done prior to LLW disposal. Current LLW shallow-land burial requirements do not allow for the expertise quantities or high concentrations of uranium to be dispositioned as LLW.

Over time, decisions will be made as to the precise path for disposition of selected inventory batches. As this occurs, the.HDPO role will shift toward logistic support for those batches. Throughout this disposition process, HDPO will pursue early identification of issues and potential problem areas and recommend actions to minimize negative impacts. 
This page intentionally left blank. 


\subsection{PROGRAMMATIC ASSUMPTIONS}

There are some unresolved issues that could impact this program plan and redirect its focus. Therefore, the following programmatic assumptions are documented as initial guidance in planning the path forward approach. Should any of these assumptions prove to be invalid, both this program plan and the implementation plans may require revision.

- The United States Enrichment Corporation (USEC)/DOE Memorandum of Agreement (MOA) will be finalized and agreed to by both parties in time to support delivery schedules.

- The privatization of the USEC will be completed in a timely manner.

- The 50t of surplus HEU to be transferred to USEC will be formally designated in a timely manner.

- The ASTM specifications for commercial nuclear reactor fuel will drive the primary characteristics of down-blended Derived Enriched Uranium (DEU) for use as reactor fuel and will heavily influence the amount of surplus HEU that must be disposed as LLW.

- Preprocessing activities needed to make surplus HEU attractive to down-blending facilities, within the planned disposition schedule, will be given necessary priority and funding.

- The design of the ES-2 shipping container and other appropriate HEU containers will be funded, and the containers will be certified and purchased in a timely manner.

- Introduction of DEU into the commercial reactor fuel market will not materially impact current industry participants.

- The surplus HEU will be "sanitized" of classified information or the blending site will obtain authorization to handle critical nuclear weapons design information.

- The surplus HEU, in the form of compounds, will be preprocessed before it is fed into down-blending operations. 
- The facilities available for processing compounds at weapons facilities will be utilized primarily in support of defense-related work and secondarily for disposition purposes.

- Surplus HEU under International Atomic Energy Agency (IAEA) inspection will require additional cost, increased time, and will reduce the options available.

- Surplus HEU, as part of environmental clean up, will be appropriately funded and schedules will coincide with disposition objectives.

- The 174t of HEU declared "excess" for defense purposes includes some portion which will be utilized in research reactors, and other nonweapons programs. That portion is not targeted at this time for dispositioning as "surplus" HEU to commercial nuclear reactor fuel or LLW, even though it is included in the current DOE breakdown of surplus HEU. However, the excess HEU used in other programs will ultimately be rendered nonweapons capable and either blended to LEU for disposal or disposed of as spent research reactor fuel. In the long term, all excess HEU will be dispositioned. At some point, the actual portion of the $174 t$ of excess HEU available for near-term surplus disposition will be clarified. 


\subsection{ROLES AND RESPONSIBILITIES}

The various participants in the surplus HEU disposition effort are introduced in Figure 5, Disposition Program Information Flow. Well-managed information flow among participants will facilitate achievement of program objectives.

Roles and responsibilities of key participants in the disposition program are outlined below. HDPO will to support, coordinate, and integrate the activities of these participants.

\section{DOE OFMD}

- Implement Secretarial directives.

- Provide policy and program integration guidance to departmental offices, heads of field offices, and HDPO.

- Coordinate activities with appropriate headquarters departmental offices; the Secretary of Energy, the Deputy Secretary of Energy, the Office of Nuclear Energy (NE), the Office of Defense Programs (DP), the Office of Nonproliferation and National Security (NN), and the Office of Environmental Management (EM).

- Provide required funding.

- Provide policy recommendation support.

- Oversee technical, economic, and business analysis.

- Oversee project management/execution for the disposition and/or sale of surplus HEU.

- Oversee Environment, Safety, and Health (ES\&H) risk assessment.

DOE Oak Ridge Operations (ORO) and Y-12 Site Office

- Provide policy support.

- Establish strategic, program, and tactical plans. 


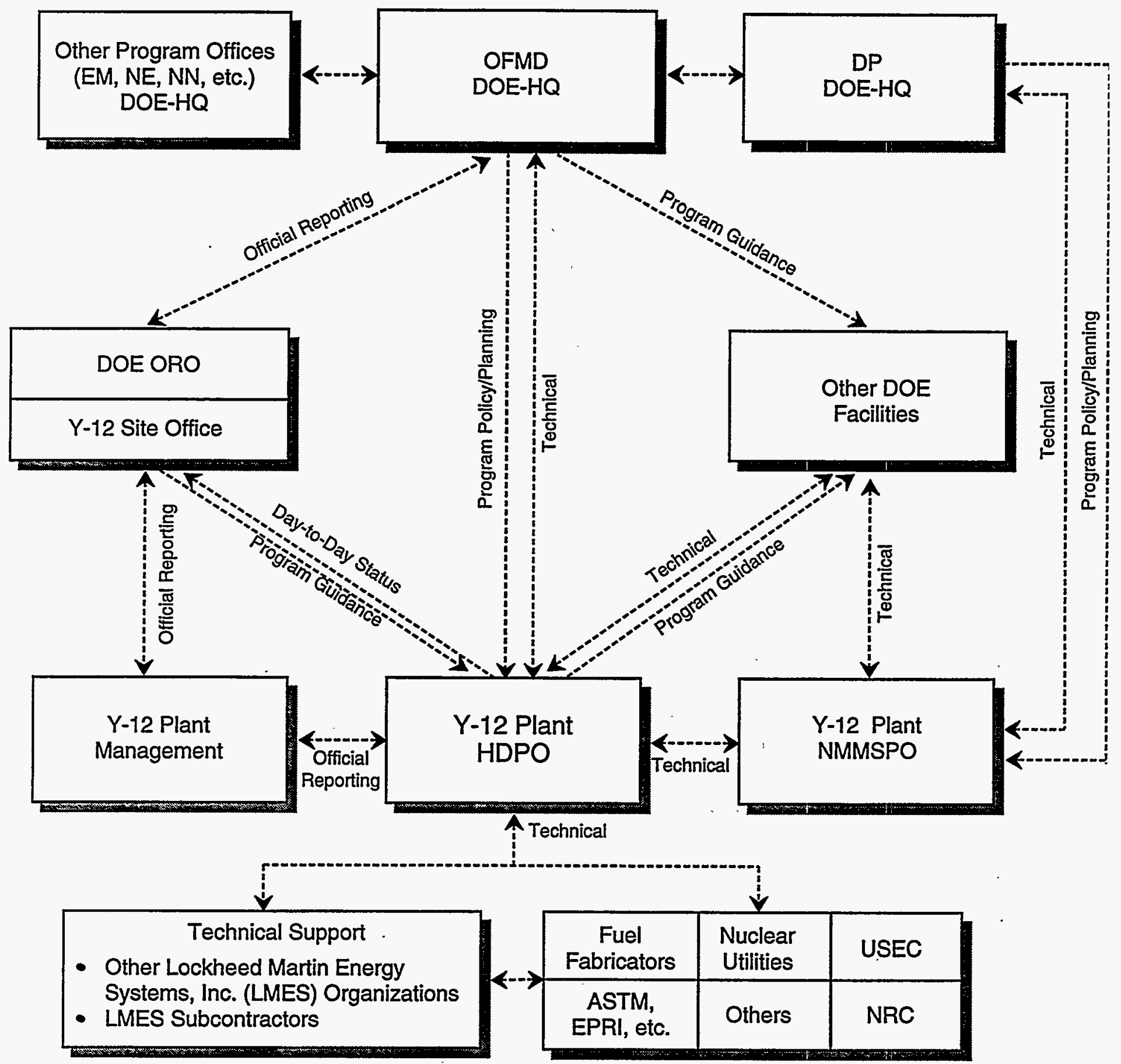

Fig. 5. Disposition Program Information Flow 
- Establish goals, roles, and responsibilities.

- Oversee information management including nuclear materials management.

- Oversee technical, economic, and business analysis.

- Provide legal and regulatory affairs coordination.

- Provide contract administration.

- Perform business development and marketing activities.

- Oversee project management/execution for disposition and/or sale of surplus HEU.

- Oversee ES\&H and risk assessment.

- Coordinate/integrate (with respect to implementation) with other key players and stakeholders.

\section{Y-12 HDPO}

- Serve as lead laboratory for Surplus HEU Disposition Program.

- Provide technical information, analysis, and assessments.

- Create and utilize a down-blending strategy.

- Make policy and strategic planning recommendations.

- Identify and assess potential roadblocks and recommend resolutions.

- Implement disposition tasks.

- Perform day-to-day planning, control, coordination, and execution.

- Develop roles, responsibilities, and goals.

- Develop action plans, schedules, and business plans.

- Provide marketing analysis and development. 
Y-12 Plant Nuclear Materials Management and Storage Program Office (NMMSPO)

- Design, implement, update, and maintain excess HEU characterization database.

- Plan and schedule projects to prepare for storage of surplus materials at the Y-12 Plant.

- Provide logistical support for safe and secure transportation of surplus HEU.

- Coordinate any preprocessing required on site.

- Establish and oversee implementation of configuration management techniques in conjunction with DOE-DP to ensure control over surplus HEU.

- Provide batch level identification and management of surplus HEU located at the Y-12 Plant and coordinate control of other inventories for consistency with the objectives of the program.

- Programmatically manage surplus inventory to ensure project accountability.

- Provide HDPO up-to-date data concerning disposition decisions.

- Provide annual nuclear materials allotments for OFMD activities.

- Coordinate and approve all nuclear material receipts, shipments, and recovery operations at the Y-12 Plant.

Other DOE Facility Nuclear Material Management Offices (with surplus HEU inventories)

- Ensure funding for and management of surplus materials until a disposition decision is implemented.

- Serve as facility representative in disposition discussions related to surplus HEU inventories on site.

- Manage and coordinate facility activities.

- Inform the Y-12 Plant NMMSPO and DOE-DP of plans or requests to change the status of facility material.

- Coordinate preprocessing required on at the facility. 
- Provide assistance and information to NMMSPO, HDPO, OFMD, and other facilities as appropriate.

- Support material characterization requirements for surplus HEU inventories at the facility.

\section{Nuclear Regulatory Commission (NRC)}

- Oversee U.S. commercial DEU fuel fabrication facilities.

- Oversee use of DEU as commercial reactor fuel in the U.S.

- Oversee use of commercial facilities for HEU down blending.

USEC

- Manage activities related to HEU transfer to USEC.

- Manage disposition and sale of DEU as commercial reactor fuel.

Companies/Facilities for Down Blending

- Keep HDPO apprised of current processing capabilities or anticipated changes.

- Inform HDPO of issues or concerns that may impact the program.

- Manage/perform down blending operations in a timely and effective manner and in accordance with all requirements (e.g., ES\&H, security). 
This page intentionally left blank. 


\section{0 · SUMMARY LEVEL SCHEDULE}

This section provides a high level overview of major program milestones in dispositioning the remaining 161t of the 174t of surplus HEU (13t was dispositioned in 1994). Schedules have been established by OFMD based on available information and may change in response to additional studies and data gathering. Several issues must be resolved before specific start and end dates can be finalized.

Major OFMD program milestones group logically into four time-frames. Near-term activities are required to support all four of these time frames.

- Today through year 6 - This period addresses $60 \mathrm{t}$ of surplus HEU. The plan requires that $10 t$ be set aside under IAEA safeguards and $50 t$ be transferred to USEC for down blending to an LEU product for commercial nuclear reactor fuel. An additional $13 t$ of the $50 t$ will be placed under IAEA oversight within the next three years.

- Year 5 through year 15 - An additional 40t of HEU will be down blended to LEU for use as commercial nuclear reactor fuel.

- Year 15 through year 20 - During this approximate five year period, 36t of HEU is expected to be dispositioned. This material is more difficult to recover but will likely be down blended to LEU for use as commercial nuclear reactor fuel.

- Year 10 through 20 - The remaining 25t of the surplus HEU will probably not be useable for reactor fuel because of form or isotopic composition. It is currently expected that this material will be down blended for LLW disposal or disposed of as spent research reactor fuel.

The HDPO will utilize these summary level guidelines as a basis for more detailed schedules which will be updated annually in the Implementation Plan. These detailed schedules will address specific activities and tasks to achieve DOE objectives. 
This page intentionally left blank. 


\subsection{BUDGET AND RESOURCE ESTIMATES}

Budget and resource estimates for addressing OFMD objectives and subsequent HDPO objectives will be defined annually in the HDPO Implementation Plan. Budget needs for specific tasks under each HDPO objective will be based on the level of effort and resources required to complete the work. The HDPO will be responsible for identifying the specific tasks and assigning Y-12 Plant personnel, subcontractors, and other resources required to complete the tasks on schedule to satisfy OFMD objectives. The OFMD will have ultimate responsibility to provide necessary funding to HDPO to support these task projections. The HDPO will manage activities against these annual budget estimates. 
This page intentionally left blank. 


\subsection{DEFINITIONS}

Disposition To destroy the weapons capability of HEU in a manner that is irreversible. In this context, disposition of HEU has two specific outcomes; LEU for commercial nuclear reactor fuel or low level radioactive waste.

Excess

The HEU declared by the President as "excess" to the national security needs of the United States.

Surplus

The portion of excess HEU which has no present or future DOE programmatic requirements (e.g., used in research reactors) and is available for disposition.

Off-spec

HEU that cannot be reasonably down blended to LEU that meets ASTM isotopic specifications for commercial nuclear reactor fuel.

HEU

Highly Enriched Uranium; uranium enriched in the ${ }^{225} U$ isotope to a level of 20 percent or greater.

LEU Low Enriched Uranium; uranium enriched in the ${ }^{25} U$ isotope to a level of less than 20 percent.

DEU

Derived Enriched Uranium; LEU derived by down blending HEU with low-assay uranium . 
This page intentionally left blank. 


\subsection{ABBREVIATIONS, ACRONYMS, AND INITIALISMS}

\begin{tabular}{|c|c|}
\hline ASTM & American Society of Testing and Materials \\
\hline$B \& W$ & Babcock and Wilcox \\
\hline DEU & derived enriched uranium \\
\hline DOE & Department of Energy \\
\hline EPRI & Electric Power Research Institute \\
\hline EU & enriched uranium \\
\hline EUO & Enriched Uranium Operations \\
\hline HDPO & Y-12 Plant Highly Enriched Uranium Disposition Program Office \\
\hline HEU & highly enriched uranium \\
\hline IAEA & International Atomic Energy Agency \\
\hline LEU & low enriched uranium \\
\hline LLW & low-level radioactive waste \\
\hline LMES & Lockheed Martin Energy Systems, Inc. \\
\hline LWR & light water reactor \\
\hline NEPA & National Environmental Policy Act \\
\hline NFS & Nuclear Fuel Services \\
\hline NMMSPO & Y-12 Plant Nuclear Materials Management and Storage Program Office \\
\hline NRC & Nuclear Regulatory Commission \\
\hline NU & natural uranium \\
\hline OFMD & Office of Fissile Materials Disposition \\
\hline $\mathrm{R} \& \mathrm{D}$ & Research and Development \\
\hline ROD & Record of Decision \\
\hline SRS & Savannah River Site \\
\hline TVA & Tennessee Valley Authority \\
\hline UNH & uranyl nitrate hexahydrate \\
\hline USEC & United States Enrichment Corporation \\
\hline $\mathrm{U}_{3} \mathrm{O}_{8}$ & triuranium octoxide \\
\hline $\mathrm{UF}_{6}$ & uranium hexaflouride \\
\hline${ }^{235} \mathrm{U}$ & uranium isotope with atomic weight of 235 \\
\hline
\end{tabular}


This page intentionally left blank. 


\section{DISTRIBUTION}

A. D. Anderson, ID

J. Andre, PNL

S. Battle, LMES/PORTS

T. M. Berg, OK

K W. Buckles, LMES/ORNL

G. W. Cagle, LMES/Y-12 Plant

R. L. Campbell, LMES/Y-12 Plant

H. Canter, MD-3

T. Cantey, SR

S. O. Cox, LMES/Y-12 Plant

S. Davies, Rocky Flats

R. D. Duncan, MD-3

B. G. Eddy, OR

F. P. Gustavson, LMES/Y-12 Plant

R. Haga, ANL-W

J. T. Hargrove, LMES/K-25 Plant

M. E. Hassler, LMES/Y-12 Plant

H. Hazelton, HEI

F. E. Healey, $\mathrm{CH}$

W. H. Hopwood, LMES/Y-12 Plant

S. R. Jones, LANL

A. B. Joy, RL

R. D. Keck, LMES/Y-12 Plant

D. Lini, Hanford EHF

K. C. Maslin, LLNL

M. S. McCormick, RFFO
J. E. Medlock, OR

M. K. Morrow, LMES/Y-12 Plant

J. W. Newton, DP-22

D. Nulton, MD-4

C. L. O'Dell, SAIC

C. E. Olson, SR

P. Parker, Pantex

J. W. Parks, OR

K. A. Pilcher, LMES/Y-12 Plant

J. A. Reafsnyder, OR

R. K. Roosa, LMES/Y-12 Plant

J. Sichler, SNL

J. Sickles, NBL

J. D. Snider, LMES/Y-12 Plant

B. H. Stelson, LMES/Y-12 Plant

J. D. Stout, LMES/Y-12 Plant

E. Stumpfl, LMES/Y-12 Plant

M. A. Thom, INEL

C. Wennes, BNL

G. J. Werkema, AL

C. K. Williams III, LMES/Y-12 Plant

T. H. Wynn, OR

Y-12 Plant Records Services,

9711-5, MS-8169 (3)

Y-12 HDPO DMC (5) 
This page intentionally left blank. 